\title{
WIKIS AND POWERPOINT AS COGNITIVE DEVELOPMENT TOOLS IN SCIENTIFIC LITERACY: A PROPOSED HEURISTIC
}

\author{
André du Plessis \\ Nelson Mandela Metropolitan University, South Africa \\ E-mail: andre.duplessis@nmmu.ac.za
}

\begin{abstract}
The overall performances in the Trends in International Mathematics and Science Study (TIMMS) and Progress in International Reading Literacy Study (PIRLS) of South African learners have been dismal to say the least and the Annual National Assessment test results of grade 3, 6 and 9 learners related to general literacy and mathematics have left a lot to be desired. Clearly this suggests that something has to be done to address this. At the same time, South African education is still suffering as a result of the legacy of apartheid and the great majority of schools are lacking basic resources such as libraries, infrastructure and Information and Communication Technology (ICT) resources, including internet connectivity. General learner literacy and ICT literacy development and usage for learning are high on the government's agenda, as is scientific literacy. However, there seems to be a dearth of 'how to' implement ICT related activities to develop reading, talking, listening and writing within a science classroom learning context with special reference to promoting scientific literacy in its fundamental sense. The theoretical and practical outline that follows attempts to assist filling the void related to the above by introducing an ICT based scientific literacy heuristic that is infused by the ICT based 'Extended Cyberhunt Approach' of Du Plessis (2010) and Du Plessis and Webb (2011, 2012, in press) and the off-line Scientific Literacy model of Webb and Villanueva (2008); Webb and Mayaba (2010) and Webb (2010). The focus of the heuristic is to develop scientific reading, talking, listening and writing, as well as to establish a different classroom learning space and experience. In addition, it adds emphasis on on-going feedback from the teacher to the learners as well as focusing on reflection and journal writing to inform teacher planning and subsequent interactions in the science classroom. The additional potential of the heuristic is not only that it offers ICT literacy skills development and the development of skills within a curriculum related science context, but also that ICT skills can be developed even without internet connectivity through using Microsoft Word and/or PowerPoint for writing development and presentation or adding Web 2.0 tools such as a Wiki to complement Microsoft Word and/or PowerPoint if connectivity is available. Research suggests that various skills such as planning, searching and researching, presentation, assessment as well as various cognitive skills can be developed when ICT is used as a cognitive tool in a 'Learning-asDesign' context, i.e. when learners (students) become the designers and composers of artefacts related to topics that are curriculum based. This paper also then forms the base for an intervention in two primary schools in the Eastern Cape Province in South Africa that has received ICT resources for the first time ever, including internet connectivity, in September 2013. Hence, the anticipated research within these two schools will explore whether this heuristic has the potential to assist with and improve scientific reading, talking, listening and writing, as well as whether this approach improves motivation and interest related to science learning and ICT literacy development, including the potential to develop planning, searching and researching, presentation, assessment as well as various associated cognitive skills.
\end{abstract}

Key words: cognitive tools, heuristic, ICT, PowerPoint, Internet, scientific literacy. 


\section{PROBLEMS \\ OF EDUCATION \\ IN THE $21^{\text {st }}$ CENTURY \\ Volume 57,2013 \\ 26 Introduction}

As a result of the discriminatory apartheid policies prior to 1994 in South Africa, the majority of South African learners are still disadvantaged, as their schools are situated in poor township areas where basic amenities are still lacking (Fleisch, 2008; Taylor, Fleisch \& Shindler, 2008). In spite of the democratic elections and the African National Congress in power since 1994, township schools do not have the same resources as more privileged schools situated in middle- and upper class neighbourhoods, in fact, spending on education has declined during the first fifteen years since the first democratic elections (Taylor, Fleisch \& Shindler, 2008). It is not just socio-economic backlogs that are a problem in the South African context, our learners in our country is also lacking access to ICT resources and internet connectivity (DoBE, 2004; 2009; Howie, Muller \& Paterson, 2005; Du Plessis, 2010) that results that our learners are still 'digital immigrants' instead of being 'digital natives' (Prensky, 2001). Yet, national curricula demand that children become computer literate and that schools should integrate ICT across the curriculum. For example the South African National Department of Education in South Africa has provided a three phase plan for schools to prepare learners to be digitally competent from 2010 (Department of Education, 2004), but in reality schools have not been supplied with ICT resources (Du Plessis, 2010). As government is not providing the majority of schools with the minimum resources on various levels, such as textbooks that are delivered on time, libraries and ablution; the Equal Education Movement has forced the minister of education to proclaim minimum norms and standards (Pinnock, 2013). In addition, our learners are also not performing well in basic literacy skills (Chisholm, 2004; Spaull, 2012; Wilkinson \& Rademeyer, 2013) as well as in mathematics and science (Human Sciences Research Council, 2006; Spaull, 2012). These backlogs are also highlighted in the international PIRLS 2006 Literacy Report (Mullis, Martin, Kennedy \& Foy, 2007) and the TIMMS 2003 Report on Mathematical- and Science Knowledge and Skills (Gonzales, Williams, Jocelyn, Kastberg, \& Brenwald, 2009).

The Department of Basic Education (DoBE) has acknowledged that ICT is paramount for learning and has provided an overview in their White Paper on e-Education (Department of Education, 2004) of the type of learning envisioned, the thinking that needs to be cultivated, the kind of ICT levels that need to be developed, and the type of school that is required in the South African context, i.e. schools that promote higher order thinking and that develop certain critical outcomes. These critical outcomes refer to for example to work together in teams, to manage themselves responsibly, to collect and analyse information, to communicate effectively to use science and technology effectively, and to employ effective learning strategies (Department of Education, 1997, 2002, 2004). Not only is the development of basic literacy skills high on the agenda of the Department of Basic Education, but the development of science skills, specifically scientific literacy from grade 1 to 9 in the primary school has been made explicit in the National Curriculum Statement (Webb, 2009). ICT implementation for teaching and learning is also important, as mentioned previously (Department of Education, 2004), but there seems to be no clear directives from the Department of Education on 'how to' use ICT for teaching and learning (Hodgkinson-Williams, 2005). It seems that the majority of schools in South Africa is still using the computer laboratory model where ICT is bolted onto the curriculum (Department of Education 2002, 2003), an aspect that has been confirmed by Du Plessis (2010). Du Plessis (2010) uses terms suggested by Jonassen, Myers and McKillop (1996) and Jonassen, Peck and Wilson (1999) in order to suggest that the predominant use of ICT resources within schools are 'learning about computers' (computer literacy), or using ICT as a tool to achieve traditional goals in a 'learning from' context instead of using ICT as a tool in a 'learning with' context that implies constructivist learning spaces (Du Plessis, 2010). 
From the above, it is thus clear that there is a need for the development of basic literacy skills, scientific skills, ICT skills, the development of the critical outcomes of the South African curriculum, as well as higher order thinking. The above mentioned aspects were also a concern for Villanueva and Webb (2008), Webb (2009) and Webb and Mayaba (2010) and hence they embarked upon scientific literacy interventions in rural areas win the Eastern Cape Province in South Africa, interventions that showed positive results pertaining to the development of reading, listening and writing skills.

Recently, two schools in rural areas in the Sundays River Valley close to Port Elizabeth and the Nelson Mandela Metropolitan University, two primary schools received computers and internet connectivity from sponsors with the aim not only to provide computer literacy skills to learners who have never before engaged with computers and the internet, but also to promote scientific literacy and mathematics through the use of ICT. In light of this and the paucity of information on the 'how to' regarding ICT usage for teaching and learning, the question that arose was, If there is a paucity of information and guidelines to assist teachers with 'how to' implement ICT for teaching and learning in order to try to address the above-mentioned aspects, is it possible to design a cognitive development tool that could be used to address the above-mentioned aspects to promote computer literacy and scientific literacy at the same time? At the same time, this cognitive tool should not only promote motivation and interest in learning, but should be novel too.

\section{Scientific Literacy}

There are numerous conceptions or interpretations of what scientific literacy is or entails (Villanueva \& Hand, 2011), but for the scope of this paper the Organistion for Economic Cooperation and Development (OECD, 2013, p. 100) definition is presented which states that scientific literacy refers to an individual's:

- "Scientific knowledge and use of that knowledge to identify questions, acquire new knowledge, explain scientific phenomena, and to draw evidence-based conclusions about science-related issues.

- Understanding of the characteristic features of science as a form of human knowledge and enquiry

- $\quad$ Awareness of how science and technology shape our material, intellectual, and cultural environments

- Willingness to engage in science-related issues, and with the ideas of science, as a reflective citizen."

(OECD, 2013, p. 100)

In order to become scientifically literate, learners (students) have to be assisted to develop good reading, writing and reasoning skills in order to assist them to engage in meaningful ways (Pearson, Moje \& Greenleaf, 2010; Webb, 2010; Webb \& Treagust, 2006) with what Pearson, Moje and Greenleaf (2010, p. 459) refer to as "the language, texts and dispositions of science" in oral and written form, as engaging in these forms lead to the development of scientific knowledge, greater understanding and hence provide opportunities to engage in public science discourse (Pearson, Moje \& Greenleaf, 2010). However, this is not easy, as learners have to be prepared to read, write and argue in a scientific medium, an academic medium that is different from the day-to-day or informal language that they speak at home and the specific scientific language that science requires (Webb, 2010). In addition, it is important to note that the reading texts or writings pertaining to science, i.e. expository (non-narrative texts), is not something in which many learners engage during their primary school years, as the focus seems to be on narrative fictional readings (Fang \& Fine, 2007). Yet, seems that expository texts are 
André du PLESSIS. Wikis and PowerPoint as Cognitive Development Tools in Scientific Literacy: a Proposed Heuristic

PROBLEMS

OF EDUCATION

IN THE $21^{\text {st }}$ CENTURY Volume 57,2013

28 becoming more and more important as learners progress through school and yet this is an area that does not receive enough attention (Fang \& Fine, 2007; Kamil \& Bernhardt, 2004), hence the importance of introducing learners to scientific readings at an early age in order to not being "left behind" (Fang \& Fine, 2007, IS, p. 3). Another aspect that is important within scientific literacy is metacognition; thinking about one's own thinking or becoming, or as Thier (2010) states, "becoming aware of their own thinking." Thier (2010, p. 34) contends that not only is metacognition a vital aspect in the scientific literacy process, but also making the teaching strategies explicit to the learners in order that they are able to make the connection between the teaching strategies and learning.

The importance of being able to question and inquire within the science domain is important as "When literacy activities are driven by inquiry, students simultaneously learn how to read and write science texts and to do science" (Pearson, Moje and Greenleaf, 2010, p. 459-460), as "promoting reading, writing and talking while 'doing science plays a vital role in effective teaching and learning [of science]” (Webb, 2010, p. 448). Thier's (2010) suggestions clearly suggest that a high premise it put on questioning, writing, finding and clarifying. The value of inquiry and writing in a scientific manner is further highlighted by Pearson, Moje \& Greenleaf (2010, p. 460) when they state that this refers to being able "think, write and shape arguments the way they [scientists] do" when learners start to engage in talk and writing related to aspects such as for example what is the problem, what is known about it and what does others write about it, how can I gather information and data about it, what can I conclude from my data and other literary sources and hence what claims can I make (Pearson, Moje \& Greenleaf, 2010).

In order for learners to become scientific literate, there are tools that could be used, i.e. talk. Wegerif and Mercer (1997) define three kinds of talk, namely disputational talk, cumulative talk and exploratory talk as forms of talk that could be 'visible' when learners are engaged in discussion. It seems that exploratory talk as an analytic tool (Webb \& Treagust, 2006) is one of the tools that seem to be useful in promoting scientific inquiry. Exploratory talk refers to critically engaging in a constructive manner with the ideas of one's peers, i.e. ideas that can be challenged with justification by offering alternative possibilities or even alternative hypotheses (Wegerif \& Mercer, 1997). In contrast, disputational talk refers to disagreement and individual decision making, hence excluding the pooling of available resources as well as criticism to enhance understanding or to explore alternatives (Wegerif \& Mercer, 1997). Cumulative talk again refers to talk that is characterised by building positively without criticism on what other peers have stated through accumulating information through repetition, confirmation and elaboration (Wegerif \& Mercer, 1997). From the above, it seems thus that exploratory talk should be encouraged, as this seems to be critical and analytical talk due to the fact that scientific reasoning and science itself seems to be informed by analytical processes. Other tools that are useful to promote scientific literacy are for example, listening skills and writing skills e.g. journal writing, reflection and recording of one's findings in a scientific notebook (Villanueva \& Webb, 2008; Webb, 2009). In order to assist learners when reading scientific texts or viewing online media with a view to support learners with their thinking, note taking and writing of science, the guidelines of Thier (2010, p. 34) seem to be useful. She provides a detailed overview when she provides the following guidelines (Thier, 2010, p. 34):

- "Underline the main ideas or topics.

- Place a dot next to the parts you want to remember.

- Put a question mark next to the parts you don't understand.

- Highlight the parts you find interesting.

- Circle the parts you agree with.

- Underline the parts you think your teacher wants you to know.

- Write notes about the information you want to remember to remind 
yourself why it is important to you.

- Write questions about parts you do not understand.

- Write notes about your thoughts and feelings.

- Write a short summary of the reading.

- For any unfamiliar words, find their definitions and use them in a new sentence"

(Thier, 2010, p. 34)

Research has shown that the discussion among students in pairs (three to four students per pair) resulted in greater achievement in test scores than when using traditional teaching methods (Osborne, 2010). It seems that debate and discussion with peers offers opportunities to make meaning or even 'new-meaning making'; hence argumentation and questioning seem to be assisting with cognitive development and conceptual understanding (Osborne, 2010). At the same time, it is important to take cognisance of the fact that this argumentation and debate are characterised by decent social interaction which values one another's arguments based upon reasonable valid claims based upon evidence (Osborne, 2010). Research conducted by Villanueva and Webb (2008), Webb (2009) and Webb and Mayaba (2010) also seems to concur with the above, including that the scientific literacy model that they have implemented, suggested positive results pertaining to learners' scientific talk, listening, reading and writing

From the literature, it appears that scientific literacy could assist to develop scientific literacy on two planes, namely the fundamental and derived senses (Norris \& Phillips, 2003). However, there seems to be an overemphasis on the derived sense (Norris \& Phillips, 2003). Villanueva and Hand (2011) argue based on references that these two senses should not be seen as separate, but rather that there is interplay between the two. In order to indicate what the fundamental and derived senses refer to, a presentation is provided in Table 1 (Yore, Pimm \& Tuan, 2007, p. 568).

Table 1. Interacting senses of scientific literacy - cognitive symbiosis (Yore, Pimm \& Tuan, 2007, p. 568).

\begin{tabular}{ll}
\hline Fundamental sense & Derived sense \\
\hline Cognitive and metacognitive abilities & Understanding the big ideas and unifying concepts of science \\
\hline Critical thinking/plausible reasoning & Nature of science \\
\hline Habits of mind & Scientific inquiry \\
Scientific language & Technological design \\
(including mathematical language) & \\
\hline Information communication technologies (ICT) & Relationships among science, technology, society, and environ- \\
& ment (STSE) \\
\hline
\end{tabular}

The focus of this study is to make a case not only for scientific literacy, but how to infuse ICT as a core component for promoting the fundamental sense through the implementation of the proposed heuristic.

\section{Barriers Pertaining to the Implementation of Scientific Literacy}

Two key elements in science are argumentation and critique, aspects that can be achieved through collaborative discourse and argumentation (Osborne, 2010). However, it seems that these two keys are not present in science education with schools (Osborne, 2010). If these key 
André du PLESSIS. Wikis and PowerPoint as Cognitive Development Tools in Scientific Literacy: a Proposed Heuristic

PROBLEMS

OF EDUCATION

IN THE $21^{\text {st }}$ CENTURY Volume 57, 2013

elements are not becoming part and parcel of science education, it could result in naivety and misconceptions about the nature of science (Osborne, 2010). Hence, it is important that learners (students) need to engage critically with science in order to come to terms with the fact that scientific knowledge is not a fixed body of knowledge, but that it is open to correction (Osborne, 2010).

It is quite possible that the two key elements are not addressed as a result of various reasons, i.e. an over-emphasis on high stakes testing and exams (Pearson, Moje \& Greenleaf, 2010 which results in following the curriculum in a step-by-step manner (Osborne, 2010), as well as the traditional teacher transmission model of knowledge presentation (Osborne, 2010) or lecturing of science. This results in teacher dependence from the learners' side, passivity from the learners', as well as uncritical engagement and very little time provided for science (and probably other subjects too) within the school week (Pearson, Moje \& Greenleaf, 2010) on the school time table. There seems thus and overemphasis on the importance of 'what to know' instead of 'how we can know' due to textbook based knowledge teaching (Osborne, 2010; Pearson, Moje and Greenleaf, 2010) or "text-centric curricula" that hampers inquirybased learning (Pearson, Moje \& Greenleaf, 2010, p. 459). This again raises the question of the importance of 'how much' to be covered is important in opposition to 'how well' can scientific aspects be dealt with in order to promote greater understanding and a more positive attitude towards science learning. The proposed heuristic in this paper has as its focus the 'how well' dimension.

\section{A Current Scientific Literacy Heuristic}

Barber, Pearson, Cervetti, Hiebert and Bravo (2012) provide a multi-modal approach related to scientific literacy in their "Seeds of Science/Roots of Reading" programme. Their approach entails linking science to real life which requires that learners read about a problem in a narrative text and then engage with the problem by examining it or modelling it. They also reflect upon their findings, talk about their findings and write what they have found by using a tool such as a storyboard to illustrate the process, including their findings (Barber et al., 2012).

Webb and Villanueva (2008); Webb and Mayaba (2010) and Webb (2010) have also provided their approach as an integrated strategy to scientific literacy in the form of a heuristic. This integrated approach is represented in Figure 1.

Webb (2009) has argued with reference to others that the development of the fundamental aspects of science is an important aspect of scientific literacy, as the latter is informed by the former (Webb, 2009; Villanueva \& Hand, 2011). With reference to the fundamental sense as proposed by Yore, Primm and Tuan (2007), the South African proposed model developed through collaboration of the Nelson Mandela Metropolitan University and partners in the United States of America (Villanueva \& Webb, 2008) and place a high premise on doing, talking, listening, reading and writing (Villanueva \& Webb, 2008; Webb, 2009; Webb \& Mayaba, 2010; Webb, 2010). 


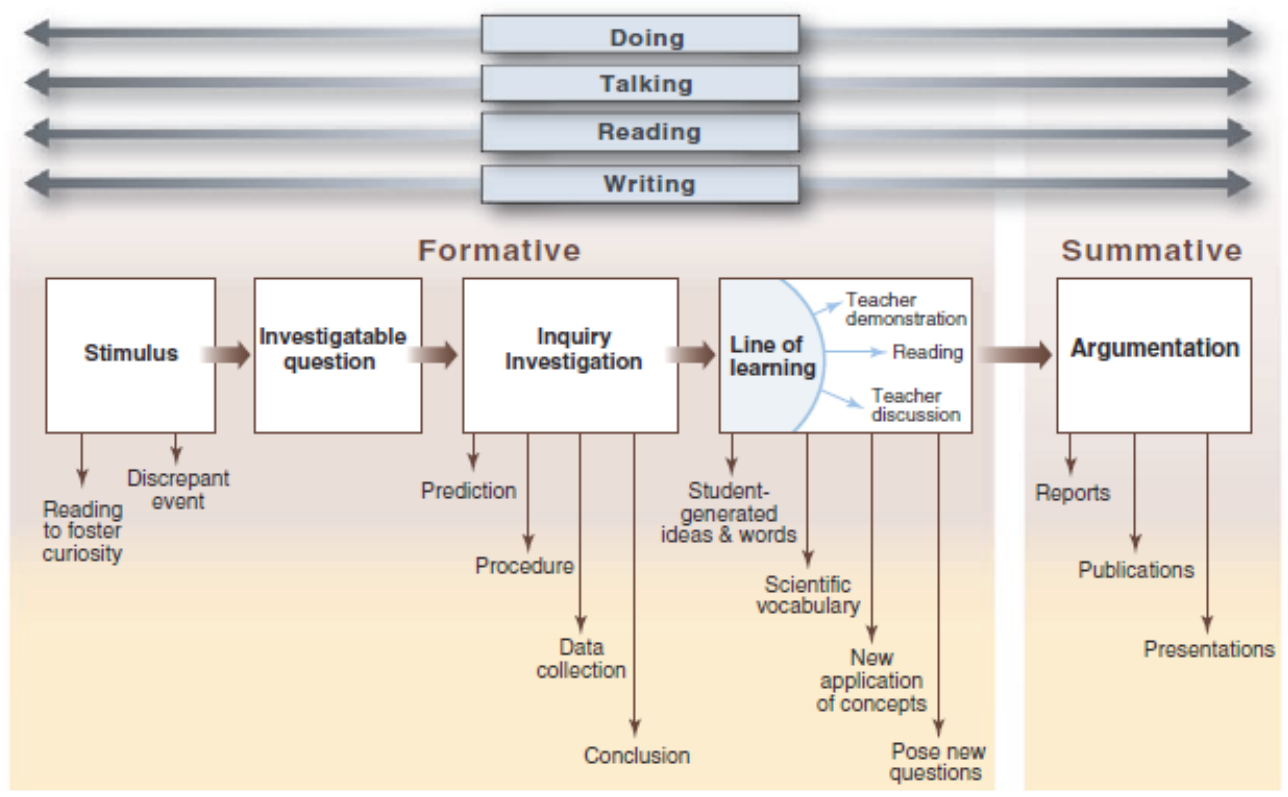

Figure 1: An integrated strategy for promoting teaching and learning toward scientific literacy (Webb, 2010, p. 449).

In brief, their approach (see Figure 1) entails that a stimulus is provided by the teacher such as reading material, concept cartoon or discrepant event that provided an opportunity as stimulus for discussion related to the stimulus (Villanueva \& Webb, 2008; Webb, 2009). This paves the way for the generation of an investigable question(s) as well as the planning and implementation of the investigation process, the 'inquiry Investigation' part in Figure 1. The inquiry part requires that learners use their scientific notebooks or journals in which they write down their prediction(s) or possible outcome of the investigation, following by indicating the procedure to be followed, followed by data collection to refute or concur with their prediction and writing their conclusion (Villanueva \& Webb, 2008; Webb, 2009). The 'line of learning' part requires that learners indicate new concepts and vocabulary that they have learned related to science, engage in further reading about the topic, engage in discussion with their teacher and peers which then could result in the formulation of new possible investigable or non-investigable question(s) that could be researched (Villanueva \& Webb, 2008; Webb, 2009). The writing process is scaffolded through phases, as the 'line of learning' part requires that learners indicate new concepts and vocabulary that they (Villanueva \& Webb, 2008; Webb, 2009). This then results in preparing learners to write and present their final report, the first part of the 'Inquiry Investigation' part being a first draft, the 'Line of Learning' part enabling them to adjust their first draft to produce a second draft and the 'Argumentation' section to produce their final product in written or poster format (Villanueva \& Webb, 2008; Webb, 2009).

This model holds promise as research conducted by Webb and Villanueva (2008); Webb and Mayaba (2010) suggest that this approach has had a positive impact on reading, writing, listening and speaking. However, one aspect seems to be missing although it could be implicitly implied, namely formal reflection on the process and experiences of 'doing' science in this manner, including providing opportunities to share in writing the meta-cognitive part of learner thinking about the process in an explicit manner. Another missing aspect seems to be on-going feedback, although this could also be an implicit aspect. 
OF EDUCATIO

IN THE $21^{\text {st }}$ CENTURY Volume 57, 2013

\section{Exploring Alternative ICT Usage: Using ICT as a Cognitive Tool in a Learning as Design Constructionist Manner}

As the proposed heuristic for scientific literacy is underpinned by ICT usage as well as constructivist and constructionist principles through 'learning-as-design', it is important to provide an overview of the current findings to ICT implementation as well as ICT usage in schools, as well as of the proposed direction and usage of ICT within the proposed learning space.

Resources appears to be one of the main complaints why schools are not implementing ICT for teaching and learning due to the fact that the Department of Basic Education in South Africa, with special reference to the Eastern Cape Province, is not providing schools in disadvantaged areas with these resources (Du Plessis, 2010). Schools in more affluent areas use part of their high school funds that the parents pay monthly, to purchase ICT equipment. However, it seems that even if a group of disadvantaged schools are provided with ICT resources and teacher professional development, the implementation of ICT for teaching and learning seems minimal (Du Plessis, 2010; Du Plessis \& Webb, 2012, in press). These findings are not new, as Bain and Weston (2012) argue that even in developed countries, the provision of ICT resources do not necessarily result in new teaching practices, improved learner results and achievement, improved ICT usage and learners being able to transfer their ICT skills to other learning in 'masterful' ways. From the above, it appears then that there are several incorrect assumptions pertaining to ICT access and its possibilities, due to the fact that ICT should not be used to perpetuate an existing practice, but should rather provide for a paradigm shift pertaining to classroom usage (Bain \& Weston, 2012). Hence, it seems fair to say that ICT should not be 'bolted-on' to the curriculum in the computer laboratory as an 'add-on' (Du Plessis, 2010) with little linkage to what learning is happening in the classroom or as a mere teacher presentation or representational tool (Hokansen \& Hooper, 2000) when teachers use PowerPoint instead of the traditional blackboard. It is thus proposed that ICTs should be available to teachers and learners whenever there is a need, for example to collect and record data, find and share information and present findings (Bain \& Weston, 2012) using ICT as a generative tool (Hokansen \& Hooper, 2000) to foster meaningful learning (Jonassen, Howland, Moore \& Marra, 2003).

Meaningful learning refers to learning "which occurs when students are [actively] making meaning" (Jonassen et al., 2003, p. 6), i.e. learners are "wilfully engaged in a meaningful task" (Jonassen et al., 2008, p. 1). The attributes of a meaningful learning space is grouped as follow (Jonassen et al., 1999; Jonassen et al., 2003; Jonassen, Howland, Moore, Marra \& Crismond, 2008):

- Active, manipulative and observant,

- Constructive, articulative, reflective,

- Intentional, reflective, regulatory,

- Authentic, complex, contextual and

- Cooperative, collaborative and conversational.

This implies a 'break-away' from the traditional 'teacher-talk' approach as well as using ICTs to complement the traditional ways of teaching and doing as it suggests a collaborative approach that contains interaction and discussion among all involved during the learning process. These advocated aspects or tenets relate to constructivism, learning as design and constructionism.

Constructivism is a theory of learning, it is not a theory or prescription regarding how to teach (Fosnot, 2005), but one is able to deduce which aspects or tenets related to learning one should plan for and include when constructing a learning space. Du Plessis (2010, p. 58) uses the ideas of several authors to construct a succinct definition of constructivism as a theory about how one knows and learns results as one constructs meaning by negotiating and sharing experiences socially, mediated through dialogue when using language as a tool as a result of our social 
interaction with one another, implying a shared social interaction (Du Plessis, 2010). This concurs with Gagnon and Collay (2001) and Marlowe and Page (2005) who posit that constructivism is knowledge construction by actively participating in the construction or co-construction of knowledge through social interaction in authentic real life contexts instead of being passive consumers of information (Gagnon \& Collay, 2001; Marlowe \& Page, 2005). From the above, it can thus be concluded that learning within constructivist learning spaces (contexts) should cater for 'meaning making' through social interaction in order to assist with understanding, applying, thinking and analysing which implies a significant turn form rote learning and memorisation (Marlowe \& Page, 2005).

Learning-as-design is based upon constructivist principles (Du Plessis \& Webb, 2011, 2012) with the premise that learning occurs as a result when learners (students) are engaged in the design of artefacts, an approach that emphasis both the process and product dimensions as important (Perkins, 1986). This approach has the potential to incorporate and develop diverse intelligences (Ivers \& Baron, 2006). Implementation of this approach could lead to changing the beliefs of teachers that learning is the transmission of knowledge from teachers to learners to learning as an active process based upon constructivist principles (Jonassen et al., 2008; Papert, 1991; Kafai \& Resnick, 1996).

The 'learning-as-design' approach extends constructivism to constructionism (Du Plessis and Webb, 2011, 2012) as constructionism refers to the creative construction of an artefact or product (Papert, 1991). In a previous publication (Du Plessis \& Webb, 2011, 2012) the opportunities that this approach affords have been indicated. Research conducted by Du Plessis (2010) suggests that the design process has the ability to develop the following aspects:

- Decision-making about what to do and how to do it,

- $\quad$ Searching, research related aspects and positive reading attitude

- Knowledge and skills related to composing questions on different cognitive levels

- $\quad$ Planning skills

- $\quad$ Computer skills and design

- $\quad$ Greater confidence in using the computer

- Reflection and evaluation of artefacts

- A greater awareness of audience,

- Interest related to learning and ICT

- Collaboration among peers

It is further argued that the searching and reading of information within a 'learning-asdesign' learning space, offers possibilities for the development and practice in context of skills such as reading, note taking, defining or creating keywords for searching purposes, the validation of the quality of knowledge, and search skills (Du Plessis \& Webb, 2011, 2012).

\section{PowerPoint and Wikis as Cognitive Development Tools for Cyberhunts}

In the previous section, it was indicated that the use of ICTs as cognitive tools in a learning-as-design learning space afford opportunities pertaining to greater retention, comprehension and the development of higher order thinking skills (HOTS). Using ICTs as a cognitive tool implies that the ICT tool that is being used become "mind-extension cognitive tool" (Derry \& Lajoie, 1993, p. 5) as the device does not become the tutor or teacher (not representing someone else's thinking), rather, the device is used as a tool by the learners to represent their own thinking learning, hence they use it as a construction tool in a constructionist manner to design and represent in a visual manner their artefact and their thinking in a generative manner. The implication thus is 'learning with' ICTs instead of 'learning from'. According Steketee (2002) 
André du PLESSIS. Wikis and PowerPoint as Cognitive Development Tools in Scientific Literacy: a Proposed Heuristic

PROBLEMS

OF EDUCATION

IN THE $21^{\text {st }}$ CENTURY

Volume 57, 2013

the visual presentation, which also implies the design of the artefact, provides opportunities to extend knowledge construction, cognitive thinking as well as metacognitive development.

PowerPoint was designed as a presentation tool and personal observation and discussions when visiting pre-service students and teachers at school during their practice teaching assessments have indicated that these students and teachers use PowerPoint as a presentation tool, replacing the chalk blackboard and the non-permanent whiteboard marker and whiteboard. Yet, PowerPoint can be used as a generative cognitive tool by learners when they present their thinking, thus moving the focus from the teacher as the transmitter of knowledge to presenting their findings that resulted from inquiry. The one advantage of PowerPoint, is that one can use it off-line as well as the fact that one can explore off-line materials as sources and still use it as a cognitive tool.

A Wiki is another cognitive tool that could be useful, as it provide a platform for learners to present their thinking and for teachers, parents or peers to track the progress on a project. However, there is one drawback, as it requires internet access and in the South African context it was alerted to that resource and infrastructure is lacking in the majority of schools. Wikis can be classified as a Web 2.0 tool, a tool to which Anderson (2007) refers to as a read and write web-based tool which distinguish itself from Web 1.0 tools that were merely reading or consumerist tools. The writing dimension which allows any person to add content online has extended Web 1.0 to Web 2.0. A Wiki such as WikiSpaces (www.wikispaces.com) is basically and online platform that allows a person(s) to store whatever they add to their wiki in the 'cloud'. A person(s) can add, edit or delete text, media (pictures, images and video), content, comments or additional pages to their Wiki and can even engage in dialogue online and share information at the same time (Du Plessis \& Webb, in press). However, one can also restrict access and/or editing and deleting by limiting users or viewers to being a guest (with little or no privileges), being student (with all privileges, little or no privileges), instructor or administrator (all privileges) (Du Plessis \& Webb, in press). Furthermore, it also allows for peer collaboration and group co-construction online in a collaborative manner and the presentation of their progress, as well as their and final artefact, a process to which Du Plessis and Webb (in press) refer to as subscribing to constructivist, constructionist and connectivist principles, "The co-construction and meaning making through social interaction online provides not only a constructivist and constructionist learning context, but also subscribes to connectivist principles" (Du Plessis \& Webb, in press). Connectivism as learning theory has been advocated by Siemens and Tittenberger (2009) in the 'Handbook of emerging technologies for learning'. When a Wiki is used, it seems that the 'six big ideas' of Anderson (2007, p. 14) are beginning to emerge, namely (1) individual production-generation of content, (2) harnessing or reigning in the power of the crowd, (3) oceans of data and information being available, (4) new platforms of participation and collaboration, (5) networking capabilities among people and (6) openness, aspects that are also featured in connectivism.

In previous publications (Du Plessis \& Webb, 2011, in press) it were indicated how the types of 'knowledges' and the various cognitive processes can be linked based upon the framework of Ainley, Banks and Flemming (2002) when learners engage in designing 'Extended Cyberhunts' (Du Plessis, 2010; Du Plessis \& Webb, 2011, in press). These links, with special reference to 'Extended Learner Designed Cyberhunts', are depicted in Table 2. The Cyberhunt strategy has been introduced and explained in previous papers (Du Plessis \& Webb, 2011, 2012, in press) by using the heuristic in Figure 2 (Du Plessis \& Webb, in press). In short, this strategy extends the Cyberhunt idea as presented by Baedke, 2003), as it not only entails the introduction of the internet in an interesting manner related to a topic in the curriculum, but that learners become the designers of Cyberhunts instead of the teachers and these learners are also introduced to the taxonomy of Bloom and/or Anderson and Krathwohl (Wilson, 2005).

When the teacher is the designer, the teacher uses software e.g. Microsoft Word or Pow- 
erPoint to type the questions pertaining to the topic and insert the associated hyperlink for the learners to explore to enable them to answer the question(s) (Du Plessis \& Webb, in press). The

PROBLEMS OF EDUCATION IN THE $21^{\text {st }}$ CENTURY Volume 57,2013 learners can then explore the questions by clicking on the hyperlink and then answer the questions either on paper or by using Microsoft Word or PowerPoint to present the questions and answers (Du Plessis \& Webb, in press).

When learners become the designers, web browsing, web browser usage, searching for information, key word creation, summarising and note taking, planning, slide creation and designing, reading and posing questions on different cognitive levels are introduced or explored further, depending on the level of skill acquisition of the learners (see Figure 2). Learners also complete a memorandum based on the questions that have been created. The heuristic for learner-designed cyberhunts has been designed based upon the concepts of Lamb, Smith and Johnson (1997), Alessi and Trollip (2002), Ivers and Baron (2006); Lehrer (1993), Du Plessis (2004), Morrison and Lowther (2002), Du Plessis (2010) and Du Plessis and Webb (2011, 2012) and consists of thirteen W's, extending and adapting the seven W's of Lamb et al. (1997). It consists of the following components: Wowing, Wanting, Wondering, Webbing, Wiggling, Weaving \& Wiking (when a Wiki is used), Wrapping-up, Waving, Wmail \& Wupload and Wising \& Wishing (Du Plessis \& Webb, 2011, 2012, in press). 
PROBLEMS

OF EDUCATION

IN THE $21^{\text {st }}$ CENTURY

Volume 57,2013

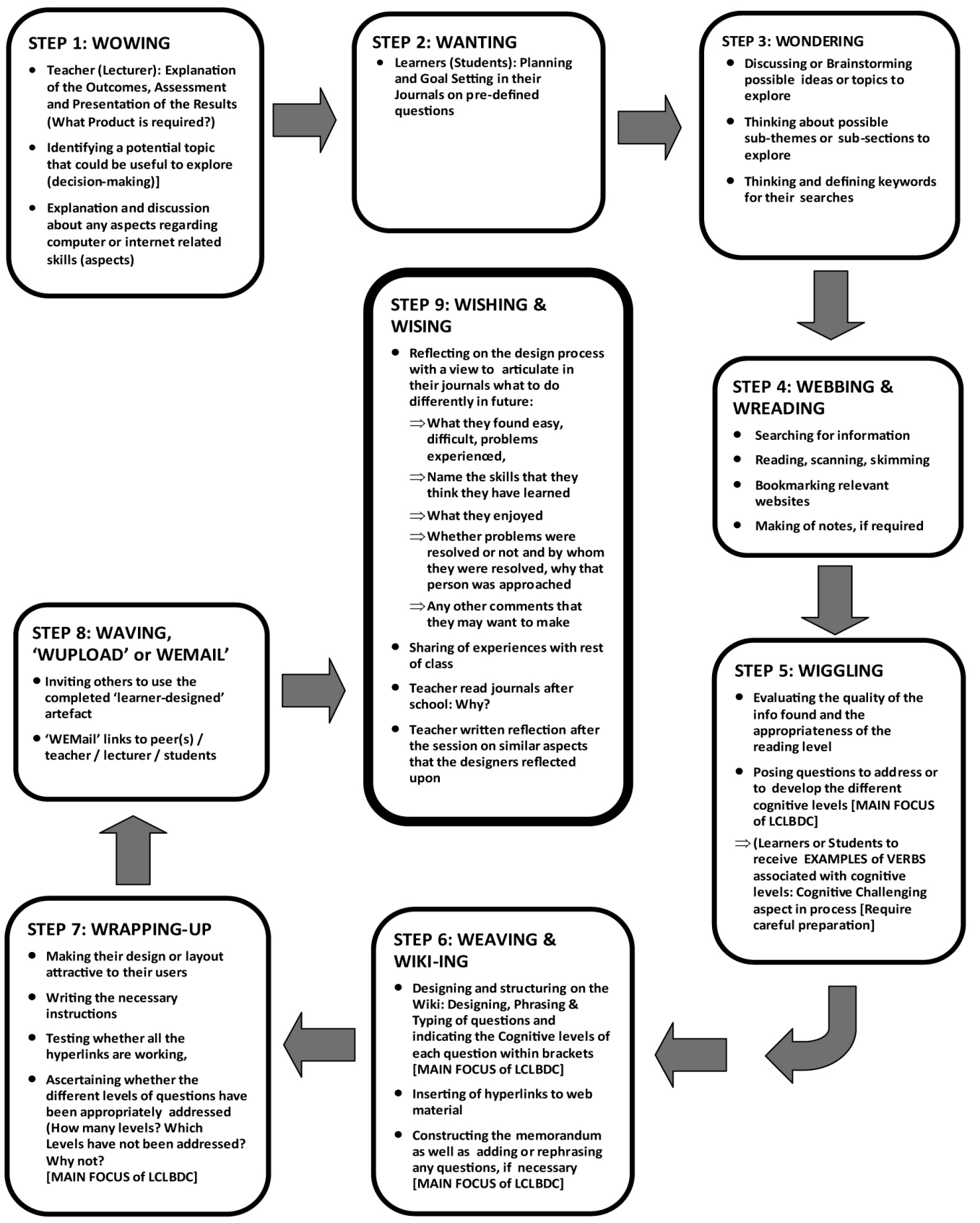

\section{Figure 2: Wiki-based extended Cyberhunt heuristic (Redrawn from Du Plessis \& Webb, in press).}

An extract from a completed learner(student)-designed PowerPoint based Cyberhunt is provided as an example in Figure 3. It is important not to equate Extended Cyberhunts with WebQuests. Although there might be some similarities, a WebQuest is teacher designed and learners do not pose questions on different cognitive levels. An overview of the similarities and differences are available in Du Plessis (2010, pp. 95-98). 


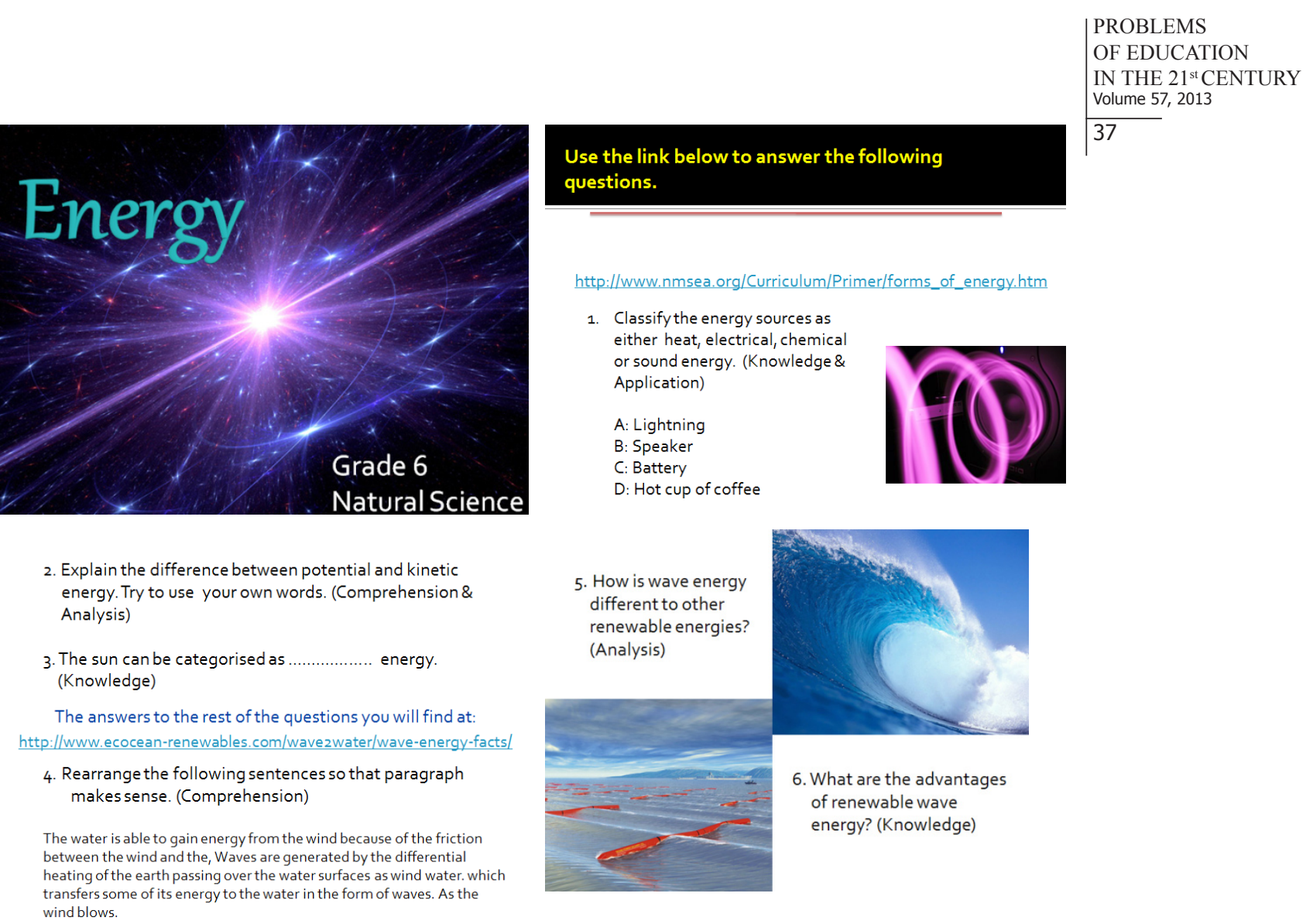

\section{Figure 3: Example of an extract of four slides of an Extended Student-designed Cyberhunt in PowerPoint.}

Table 2 indicates how the various aspects pertaining to learner-designed Cyberhunts, relate to the types of knowledge and the different cognitive processes. 
PROBLEMS

OF EDUCATION

IN THE 21 $21^{\text {st }}$ CENTURY
Volume 57,2013

Table 2. Further adapted framework for knowledge and cognitive dimension development when implementing the LCLBDEC and when incorporating reflective journal writing (Du Plessis, 2010, p. 113; Du Plessis \& Webb, 2011, p. 1202; Du Plessis \& Webb, in press).

\begin{tabular}{|c|c|c|c|c|}
\hline \multirow[b]{2}{*}{$\begin{array}{l}\text { Cognitive } \\
\text { processes }\end{array}$} & \multicolumn{4}{|c|}{ TYPES OF KNOWLEDGE } \\
\hline & $\begin{array}{l}\text { FACTUAL } \\
\text { (Basic informa- } \\
\text { tion) }\end{array}$ & $\begin{array}{l}\text { CONCEPTUAL } \\
\text { (How basic information } \\
\text { connects) }\end{array}$ & $\begin{array}{l}\text { PROCEDURAL } \\
\text { (Ways on how to do } \\
\text { something as well } \\
\text { as knowledge of the } \\
\text { criteria used) }\end{array}$ & $\begin{array}{l}\text { METACOGNITIVE } \\
\text { (Thinking about } \\
\text { one's own thinking or } \\
\text { progress) }\end{array}$ \\
\hline $\begin{array}{l}\text { REMEMBERING } \\
\text { (Recall) }\end{array}$ & $\begin{array}{l}\text { Learners } \\
\text { provide their } \\
\text { answers to } \\
\text { factual level } \\
\text { posed ques- } \\
\text { tions in the } \\
\text { Cyberhunt. }\end{array}$ & & $\begin{array}{l}\text { Learners recall } \\
\text { certain design } \\
\text { processes and } \\
\text { procedures }\end{array}$ & \\
\hline \multirow[t]{2}{*}{$\begin{array}{l}\text { UNDERSTAND- } \\
\text { ING (Providing a } \\
\text { summary, } \\
\text { comparing or clas- } \\
\text { sifying } \\
\text { something) }\end{array}$} & & $\begin{array}{l}\text { Learners provide } \\
\text { answers to the under- } \\
\text { standing level } \\
\text { posed questions in the } \\
\text { Cyberhunt }\end{array}$ & & $\begin{array}{l}\text { Reflect on ideas and } \\
\text { feedback from inter- } \\
\text { action with peers as } \\
\text { a result of } \\
\text { collaboration and } \\
\text { social } \\
\text { interaction }\end{array}$ \\
\hline & & & $\begin{array}{l}\text { Learners provide } \\
\text { their answers } \\
\text { to the applying } \\
\text { level questions by } \\
\text { providing possible } \\
\text { procedures, if } \\
\text { required }\end{array}$ & \\
\hline $\begin{array}{l}\text { APPLYING } \\
\text { (Applying or } \\
\text { carrying out a } \\
\text { procedure) }\end{array}$ & $\begin{array}{l}\text { Learners are } \\
\text { using other } \\
\text { learners' } \\
\text { created } \\
\text { products: } \\
\text { Cyberhunts }\end{array}$ & $\begin{array}{l}\text { Learners embark on } \\
\text { finding ways in which } \\
\text { they can 'fix' gaps in } \\
\text { their knowledge, } \\
\text { conceptual frame- } \\
\text { works, } \\
\text { procedures, skills and } \\
\text { misconceptions or } \\
\text { partial conceptions }\end{array}$ & $\begin{array}{l}\text { Learners plan the } \\
\text { project, project } \\
\text { management and } \\
\text { time manage- } \\
\text { ment, search } \\
\text { skills, defining } \\
\text { keywords, posing } \\
\text { questions on } \\
\text { different cognitive } \\
\text { levels, organisa- } \\
\text { tion and repre- } \\
\text { sentation skills, } \\
\text { presentation skills, } \\
\text { reading, note tak- } \\
\text { ing, defining or } \\
\text { creating keywords }\end{array}$ & $\begin{array}{l}\text { Reflect on ideas and } \\
\text { feedback from inter- } \\
\text { action with peers as } \\
\text { a result of } \\
\text { collaboration and } \\
\text { social } \\
\text { interaction }\end{array}$ \\
\hline
\end{tabular}




\begin{tabular}{|c|c|c|c|c|c|}
\hline & & & & & \begin{tabular}{|l} 
PROBLEMS \\
OF EDUCATION \\
IN THE 2 1 st CENTURY \\
Volume 57,2013
\end{tabular} \\
\hline $\begin{array}{l}\text { ANALYSING } \\
\text { (Investigating } \\
\text { something) }\end{array}$ & & $\begin{array}{l}\text { Learners provide } \\
\text { answers to analysing } \\
\text { level questions in the } \\
\text { Cyberhunt }\end{array}$ & $\begin{array}{l}\text { Quality of note } \\
\text { taking, defining } \\
\text { and/or creating } \\
\text { keywords, valida- } \\
\text { tion of the quality } \\
\text { of knowledge }\end{array}$ & $\begin{array}{l}\text { Reflection: By } \\
\text { completing journals } \\
\text { to reflect on what } \\
\text { they have learned } \\
\text { (skills, knowledge, } \\
\text { procedures, } \\
\text { etc.) } \\
\text { Reflect on ideas and } \\
\text { feedback from inter- } \\
\text { action with peers as } \\
\text { a result of } \\
\text { collaboration and } \\
\text { social interaction }\end{array}$ & \begin{tabular}{|l|}
39 \\
\end{tabular} \\
\hline $\begin{array}{l}\text { EVALUATING } \\
\text { (Assessing a } \\
\text { product, } \\
\text { process or some- } \\
\text { thing else based } \\
\text { on criteria) }\end{array}$ & $\begin{array}{l}\text { Learners } \\
\text { assess their } \\
\text { own progress } \\
\text { as well as } \\
\text { other learn- } \\
\text { ers' answers } \\
\text { or presenta- } \\
\text { tions }\end{array}$ & $\begin{array}{l}\text { Learners assess their } \\
\text { own and other learners' } \\
\text { answers or presenta- } \\
\text { tions }\end{array}$ & $\begin{array}{l}\text { Learners assess } \\
\text { their own and } \\
\text { other learners' } \\
\text { quality of the de- } \\
\text { signed Cyberhunt } \\
\text { based upon a } \\
\text { checklist or } \\
\text { rubric } \\
\text { Learners assess } \\
\text { their own and } \\
\text { other learners' } \\
\text { answers or pres- } \\
\text { entations }\end{array}$ & $\begin{array}{l}\text { Reflection: By } \\
\text { completing journals } \\
\text { to reflect on their } \\
\text { own progress based } \\
\text { upon evaluation } \\
\text { issues such as e.g. } \\
\text { which goals have } \\
\text { you reached? } \\
\text { Which goals were } \\
\text { not reached? } \\
\text { (Provide explana- } \\
\text { tions or reasons) } \\
\text { (Reflect on all of the } \\
\text { design skills) }\end{array}$ & \\
\hline $\begin{array}{l}\text { CREATING } \\
\text { (Producing a } \\
\text { product, } \\
\text { planning or design- } \\
\text { ing a product or } \\
\text { procedure) }\end{array}$ & & $\begin{array}{l}\text { Learners create their } \\
\text { own Cyberhunts in a } \\
\text { group or as individuals. }\end{array}$ & & $\begin{array}{l}\text { Learners reflect in } \\
\text { their } \\
\text { journals on how well } \\
\text { they have designed } \\
\text { it and what changes } \\
\text { they should make } \\
\text { the next time. }\end{array}$ & \\
\hline
\end{tabular}

\section{ICT Heuristic for Scientific Literacy: Using PowerPoint and/or Wikis}

Villanueva and Webb (2008), Webb (2009) and Webb and Mayaba (2010) have indicated that reading, writing, listening and speaking are pillars on which their scientific literacy heuristic is embedded upon as these aspects help with language development. Their heuristic is similar to Barber et al.'s (2012) multimodal approach which entails 'Do-It', 'Talk-It', 'Read-It' and 'Write-It'. It seems that there are similarities, but at the same time it appears that the Villanueva and Webb (2008), Webb (2009) and Webb and Mayaba (2010) model are more comprehensive as it includes more opportunities for language development than that of Barber et al. 's (2012), but then the context seems to be different as the South African model has as its focus the development of science and language development of English at second language level, as English as second level medium of instruction is the language of instruction in the majority of schools (Webb, 2009; Webb \& Mayaba, 2010). However, it was argued previously in this paper that it seems that their heuristic is not catering for reflection on the process itself, an aspect that is vital in the learning-as-design approach to which was alluded previously. Furthermore, it does 
André du PLESSIS. Wikis and PowerPoint as Cognitive Development Tools in Scientific Literacy: a Proposed Heuristic

PROBLEMS

OF EDUCATION

IN THE $21^{\text {st }}$ CENTURY

Volume 57,2013

not indicate to the learners what the outcomes of the inquiry are, nor what type of final product is required of how it will be assessed. Equally important, their heuristic does not indicate continuous teacher feedback to learners regarding their progress as an aspect, neither which tool or tools could be used for feedback purposes. Hence, the importance of the learner journal writing at the beginning and end of each science period, as reading the learner reflections captured in their journals could be useful for planning for assistance with reference to subsequent science contact sessions with the learners. Assistance to learners in whatever form is vital as this Zone of Available Assistance (ZAA) (Luckin, 2010) has the potential to provide support and change within the learners' current thinking or schemata, hence the quality of the $Z A A$ could have a profound impact on the learners' Zone of Proximal Adjustment (ZPA) (Luckin, 2010).

Keeping the above in mind, as well as the words of Hokansen and Hooper (2000) that ICT implementation's focus should be the generation of thinking, it is important to cater for the above-mentioned aspects as well as the constructivist principles alluded to in a previous section. The rationale to include the use of ICT in scientific literacy development is based on the premise of Yore, Primm and Tuan (2007) who suggest that ICTs should form part of the development of the fundamental sense of scientific literacy, as the fundamental sense serves as the foundation which prepares one to cross to the derived sense (Webb, 2009). Reading is an important aspect of the scientific literacy approach as it is through reading that Webb and Mayaba (2010, p. 36) argue that reading of science literature "aims at enhancing reading to learn science and learning to read for science."

Using ICT for scientific literacy holds promise to transcend traditional teaching approaches and could enable teachers to explore with learning in an alternative classroom context (Bain \& Weston, 2012). The traditional written and paper-based scientific notebooks could be replaced by Microsoft Word and PowerPoint as software 'notebooks' that records their findings and pre-writings or by using Wiki based cloud based tools as recording tool (www.wikispaces. com), hence, helping learners to what Villanueva and Webb (2008) refer to, with reference to others, as making their thinking explicit and visible to all, which will include attitudes, how learners think including possible misconceptions that they might have. The whole process actually assists learners with an introduction to how scientists write-up science (Webb, 2010). When learners thus become the designers and actively participate in the science process by using this scientific literacy model, it is argued that science as a practice of mere illustration and telling by teachers are transcended, as these practices are not inquiry based (Gott \& Dugan, 1995).

Based on the above, it seems that both the traditional 'Teacher-designed Cyberhunt approach' and the 'Extended Learner-designed Cyberhunt approach' holds promise not only to develop reading, writing, listening and speaking, but also several other skills alluded to in Section 5. The current 'Teacher-designed Cyberhunt approach' and the 'Extended Learner-designed Cyberhunt approach' consisting of thirteen W's as indicated in Section 6, can easily be adapted as is to science as context. However, it will not replicate the scientific literacy inquiry, as it does not require in its current design the investigation of an investigable question, making predictions, collecting raw data as well as writing findings based upon the raw data. However, it does offer the introduction of the internet, computer literacy skills within the subject area context and the exploration of scientific concepts for possible further investigation. It also requires learners to find and explore scientific based texts on a their level of understanding if they become the designers, as well as posing realistic questions on different cognitive levels that their peers could explore. Hence, it does also offer opportunities of discussion and different levels of talk when learners co-design an 'Extended Learner-designed Cyberhunt'. Critically looking at the heuristic represented by Figure 2, it becomes evident that it does offer opportunities to develop aspects of 'Do-It', 'Talk-It', 'Read-It' and 'Write-It' (Barber et al. 2012).

Both the teacher-designed and learner-designed Cyberhunt approach can be adapted to replicate and extend the model of Villanueva and Webb (2008), Webb (2009), Webb and 
Mayaba (2010) and at the same time develop the doing, talking, reading, listening and writing dimensions. This newly ICT based scientific literacy heuristic is presented by means of Figure 4 and is based on the heuristic of Du Plessis \& Webb (2011, in press), as well as the infusion of the principles of Villanueva and Webb (2008), Webb (2009), Webb and Mayaba (2010). This heuristic is not discussed in detail within the text, as Figure 4 presents a detailed overview. What is important to note, is that talking, listening, reading and writing happens continuously and not just at one specific point. The suggestions of Thier (2010) alluded to in a previous section, could also be planned for during the process.

With reference to Figure 4, it is important to note that a specific W's are not always specific to just one of the boxes of the Villanueva and Webb (2008), Webb (2009), Webb and Mayaba (2010) model, as some of the W's can form part of different boxes in the newly proposed heuristic. It is important to note that the learners make predictions and explore procedures that are web-based or text based and that the data that they collect can be derived from the web or from physical data generation and collection. In addition, a new $\mathrm{W}$ is added to the heuristic, namely 'Watering'. 'Watering' refers to the stimulus, i.e. 'watering' the fertile scientific soil for the germination of new thinking and investigations related to science.

Another aspect that is key in the heuristic, is reflection about the process (learning, webbing, collaborating and designing), as reflection forms and integral part of this heuristic. As the normal school day allows for between 30 to 60 minutes of Science Subject periods at a time, the reflection can take place at the end of every science period on journal sheets. Suggested questions that are not related to the scientific learning itself, but more regarding the learning process, could include examples such as the following (Du Plessis, 2010; Du Plessis \& Webb, 2011, 2012, in press):

- What are my goals for this session?

- What have I done during the session? Write below and also tick what you have achieved by marking with a $\sqrt{ }$ next to the goal written.

- What have I learned during this session?

- What are my concerns after the session today?

- Why am I concerned about this?

- What problems do I experience at the moment?

- Why am I concerned about these problems?

- What was difficult for me today and why?

- What have I enjoyed today and why?

- What did I not enjoy today and why?

- What problems did I experience?

- If I did experience problems, were the problems solved and by whom?

- How was the problem solved?

- Why did you ask this person(s) to help you to solve your problem(s)?

- What will I do differently next time?

- Any other comments that you wanted to make about the project? Write it down. (It can be positive, negative, what you are thinking about, etc.)

The teacher should read these journal sheets and use it to inform preparation and planning for the next science contact session in order to assist learners where possible.

PROBLEMS

OF EDUCATION

IN THE $21^{\text {st }}$ CENTURY

Volume 57,2013 
PROBLEMS OF EDUCATION IN THE $21^{\text {st }}$ CENTURY Volume 57, 2013



Figure 4: An ICT based heuristic to promote scientific literacy in a fundamental sense. 
Levels of Knowledge, Skills and Cognition Development for Scientific Literacy: ICT Possibilities of Using the Proposed Heuristic

In Section 6, Table 4 was used to indicate the possibilities that the 'Learner-designed' Cyberhunt approach affords related to how the various aspects during the design process are infused with reference to the cognitive processes and the types of associated knowledges. By using a blank table such as the one in Table 4 , it is argued that one would be in a position to map in a similar manner than in Table 4 how the proposed ICT based scientific literacy heuristic can be linked to the various cognitive processes and knowledge types. It is therefore suggested that this heuristic holds promise as it would be able to assist with the development of various cognitive processes and types of knowledge, hence, suggesting a multitude of possibilities.

\section{Lenses for Analysing Learning by Using the Proposed Heuristic}

It is beyond the scope of this overview to provide an overview of theoretical lenses that could be utilised to explain the perceptions, experiences and results of research which implements the proposed heuristic in its various forms. However, it seems that for the purpose of mixed research (quantitative and qualitative data) and qualitative interpretive designs or even case studies, activity theory (Hardman, 2005a, 2005b, 2007; Jonassen, 2002; Murphy \& Rodriguez-Manzanares, 2008; Roth \& Lee, 2007), learning as complexity (Beswick, Watsom \& de Geest, 2007; Davis \& Simmt, 2003, Davis \& Sumara, 2008; Sinclair, 2004), learning in communities of practices which refers to community, identity, meaning and practice (Wenger, 1998) and the role of dialogue and talk pertaining to understanding (Wegerif \& Mercer, 1997) and the conversational framework pertaining to the design of the heuristic and the dialogue and interaction that occurred (Laurillard, 1998, 2002) seem to be viable theoretical perspectives to interpret the data, depending on the research questions being posed.

In addition, the use of the RAVENS test as well as Literacy Tests could be useful data gathering tools used in a pre- and post-tests with controlled and uncontrolled groups to ascertain whether there was an improvement in the domains of cognitive development and literacy.

\section{Conclusion and Possible Research Agenda}

The purpose of the theoretical and practical overview presented, was to make a case for the use ICT resources and the internet to promote scientific literacy through the usage of a Wiki and/or PowerPoint during which learners become the designers of a scientific literacy based product by using these ICT resources as cognitive tools. Hence, it was argued that the presented heuristic and the various aspects related to 'learners-being-designers' through utilising ICT resources, afford learners opportunities to develop several cognitive skills and knowledges while they are engaged in a scientific literacy project. The theoretical perspectives and areas of possible development have been indicated.

Scientific literacy has as its focus the development of the fundamental sense that includes ICTs. The development of the fundamental sense seems to be a prerequisite for the derived sense. As our learners of today, even those from disadvantaged contexts, are born as digital natives it is imperative that we start to implement the usage of the tools that are part of their everyday lives. However, what is important is not only the infusion of ICT tools, but also to ascertain whether these tools hold promise with reference to the following, mentioning only a few possibilities:

- Motivation and interest pertaining to science learning,

- Improvement in reading, talking and writing science 
André du PLESSIS. Wikis and PowerPoint as Cognitive Development Tools in Scientific Literacy: a Proposed Heuristic

PROBLEMS

OF EDUCATION

IN THE $21^{\text {st }}$ CENTURY

Volume 57, 2013

- Improvement pertaining to general literacy

- Changes in attitudes and perception to science and ICT

- The development of ICT skills within contexts

- Aspects that are problematic with reference to the implementation of the heuristic, as well as positive aspects

- Learners' experiences related to learning in communities of practice

The above aspects are only a few of many possibilities that the implementation of this scientific ICT based heuristic could explore. It is therefore important to establish communities of practice globally to implement this heuristic and to co-navigate and explore its possibilities, as well as how it can be improved and refined.

\section{References}

Ainley, J., Banks, D. \& Fleming, M. (2002). The Influence of IT: Perspectives from five Australian schools. Journal of Computer Assisted Learning, 18, 395-404.

Alessi, S. M., \& Trollip, S. R. (2001). Multimedia for learning: Methods and Development. Boston: Allyn and Bacon.

Anderson P. (2007). What is Web 2.0? Ideas, technologies and implications for education. JISC Technology \& Standards Watch, Feb. 2007. Retrieved 22 September 2013 from www.jisc.ac.uk/ media/documents/techwatch/tsw0701b.pdf

Baedke, J. (2003). Using Web-Based Research Activities - CyberHunts, WebQuests, PBL++MM: How Do You Choose? Virginia Society for Technology in Education. 17(2), 5-10. Retrieved 22 September 2013 from http://www.vste.org/documents/vj_1702_all.pdf

Bain, Alan \& Mark E. Weston. (2012). The Learning Edge: What Technology can do to Educate All Children. New York: Teachers College Press.

Barber, J., Pearson, P.D., Cervetti, G, Hiebert, E.H. \& Bravo, M. (2012). Seeds of Science/Roots of Reading: Program Overview, Program Components and Features. The Regents of the University of California. Retrieved 22 September 2013 from http://www.scienceandliteracy.org/sites/ scienceandliteracy.org/files/pdf/SEEDS_Program_Overview_Sections_A_and_B.pdf

Beswick, K., Watson, A., \& De Geest, E. (2007). Describing Mathematics Departments: The Strenghts and Limitations of Complexity Theory and Activity Theory. Proceedings of the $30^{\text {th }}$ annual conference of Mathematics Education Research Group of Australasia, MERGA Inc. 2007. Retrieved 22 September 2013 from http://www.merga.net.au/documents/RP52007.pdf

Chisholm, L. (2004). The quality of primary education in South Africa. Background Paper Prepared for UNESCO Education for All Global Monitoring Report. 13th April 2004. Retrieved 22 September 2013 from http://www.hsrc.ac.za/research/output/outputDocuments/2872_ Chisholm_Thequalityofprimary.pdf

Davis, B., \& Simmt, E. (2003). Understanding learning systems: Mathematics education and complexity science. Journal for Research in Mathematics Education, 34 (2), 137-167.

Davis, B., \& Sumara, D. (2008). Complexity as a theory of education. Transnational Curriculum Inquiry, 5 (2), 33-44. Retrieved 20 September 2013 from http://nitinat.library.ubc.ca/ojs/inded.php/tci

Department of Education [DOE] (1997). Curriculum 2005: Lifelong Learning for the 21 $1^{\text {st }}$ Century - A User's Guide. Pretoria: Department of Education.

Department of Education [DOE] (2002b). Strategy for Information and Communication Technology in Education [SICTE]. Department of Education and Department of Communications, 22 January 2002.

Department of Education [DOE] (2004). Transforming Learning and Teaching through Information and Communication Technologies. (Draft White Paper on e-Education, Government Gazette, 246 August 2004): Gazetted Version. Retrieved 22 September 2013 from http://us-http://cdn. creamermedia.co.za/assets/articles/attachments/01528_draftwhitepaper.pdf

Derry, S. J., \& Lajoie, S. P. (1993). A Middle Camp for (Un) intelligent Instructional Computing: An Introduction. In S.P. Lajoie and S.J. Derry (Eds.), Computers as Cognitive Tools (pp. 1-11). Hillsdale, NJ: Lawrence Erlbaum. 
Du Plessis, A. (2010). The Introduction of cyberhunts as a teaching and learning strategy to guide teachers towards the integration of computer technology in schools. Unpublished $\mathrm{PhD}$ Thesis, Nelson Mandela Metropolitan University: South Africa. Retrieved 20 September 2013 from http://www.nmmu.ac.za/documents/theses/Thesis\%20with\%20Appendices.pdf

Du Plessis, A., \& Webb, P. (In press). A heuristic for higher level student cognitive thinking and questioning through collaborative student designed wiki-based Cyberhunts. Seventh International Conference on Science, Mathematics and Technology Education to be held in Muscat, Oman from November 4 to 7, 2012.

Du Plessis, A., \& Webb, P. (2012). Digital immigrant teacher perceptions of an extended Cyberhunt strategy. Australasian Journal of Educational Technology, 28 (2), 341-363.

Du Plessis, A., \& Webb, P. (2011). An extended Cyberhunts strategy: Learner centred learning-by-design. Australasian Journal of Educational Technology, 27 (7), 1190-1207.

Fang, Z., \& Fine, J. (2007). Teaching for Comprehending: Improving Students' Expository Reading. Flare Centre, University of Central Florida. Retrieved 22 September 2013 from http://education. ucf.edu/mirc/docs/pp/FLaRE\%20Professional\%20Paper\%20-\%20Teaching\%20for\%20 Comprehending\%20-\%20Improving\%20Students\%27\%20Expository\%20Reading.pdf

Fleisch, B. (2008). Primary Education in Crisis: Why South African Schoolchildren Underachieve in Reading and Mathematics. Cape Town: Juta.

Gagnon, G. W., \& Collay, M. (2001). Constructivist Learning Design. Thousand Oaks, California: Corwin Press.

Gagnon, G.W., \& Collay, M. (2006). Constructivist Learning Design: Key Questions for Teaching to Standards. Thousand Oaks, California: Corwin Press.

Gonzales, P., Williams, T., Jocelyn, L., Roey, S. Kastberg, D. \& Brenwald, S. (2009). Highlights From TIMSS 2007: Mathematics and Science Achievement of U.S. Fourth-and Eighth-Grade Students in an International Context, September 2009. Retrieved 22 September 2013 from http://nces. ed.gov/pubs2009/2009001.pdf

Hardman, J. (2005a). Activity theory as a potential framework for technology research in an unequal terrain. South African Journal of Higher Education, 19 (2), 378-392.

Hardman, J. (2005b). An exploratory case study of computer use in a primary school mathematics classroom: New technology, new pedagogy? Perspectives in Education, 23 (4), 99-111.

Hardman, J. (2007). Making sense of the meaning maker: tracking the object of activity in a computerbased mathematics lesson using activity theory. International Journal of Education and Development using Information and Communication Technology (IJEDICT), 3 (4), 110130.

Hodgkinson-Williams, C. (2005). Dust on the Keyboards: Policy Gaps in the Integration of ICT into the South African Curriculum. Proceedings of the 8th IFIP World Conference on Computers in Education 4-7 July. Stellenbosch: University of Stellenbosch.

Hokanson, B., \& Hooper, S. (2000). Computers as cognitive media: examining the potential of computers in education. Computers in Human Behavior, 16, (2000), 537-552.

Howie, S. J, Muller, A., \& Paterson, A. (2005). Information and Communication Technologies in South African Secondary Schools. Cape Town: SITES, HSRC Press.

Human Sciences Research Council. (2006). Mathematics and Science Achievement at South African Schools in TIMMS 2003. Cape Town: HSRC Press.

Ivers, K. S., \& Baron, A.E. (2006). Multimedia projects in education: Designing, Producing and Assessing. Westport, Conn: Libraries Unlimited.

Jonassen, D. H. (2002). Learning as activity. Educational Technology, 42 (2), 45-51.

Jonassen, D. H., Howland, J., Moore, J., \& Marra, R. M. (2003). Learning to Solve Problems with Technology: A Constructivist Perspective. New Jersey: Merrill, Prentice Hall.

Jonassen, D. H., Howland, J., Moore, J., Marra, R. M., \& Crismond, D. (2008). Meaningful Learning with Technology. New Jersey: Merrill, Prentice Hall.

Jonassen, D. H., Peck, K. L., \& Wilson, B. G. (1999). Learning with Technology: A Constructivist Perspective. New Jersey: Pearson, Merrill Prentice Hall.

Jonassen, D. H., Myers, J. M., \& McKillop, A. M. (1996). From Constructivism to Constructionism: Learning with Hypermedia/Multimedia rather than from it. In B.G. Wilson (Ed.), Constructivist Learning Environments: Case Studies in Instructional Design (pp. 96-106). New Jersey: Educational Technology Publications. 
André du PLESSIS. Wikis and PowerPoint as Cognitive Development Tools in Scientific Literacy: a Proposed Heuristic

PROBLEMS

OF EDUCATION

IN THE $21^{\text {st }}$ CENTURY Volume 57,2013

Kafai, Y. B., \& Resnick, M. (1996). Introduction. In Y. Kafai and M. Resnick (Eds.), Constructionism in practice: Designing, thinking and learning in a digital world (pp. 1-8). Mahway, NJ: Lawrence Erlbaum Associates.

Kamil, M., \& Bernhardt, E. (2004). The science of reading and the reading of science: Success, failures and promises in the search for prerequisite reading skills for science. In E. W. Saul, Ed. Crossing Borders in Literacy and Science Instruction: Perspectives on Theory and Practice. (pp. 123139). Newark, DE: International Reading Association.

Lamb, A., Smith, N., \& Johnson, L., (1997). Wondering, wiggling, and weaving: A new model for projectand community-based learning on the web. Learning and Leading with Technology, 24 (7), 6-13.

Laurillard, D. (1998). How can interactive multimedia enhance learning? IV Congresso RIBIE (pp. 1-13). Brasilia. Retrieved 22 September 2013 from http://sm.dei.uc.pt/ribie/docfiles/ txt200342319328001_DIANNE\%20LAURILLARD.PDF

Laurillard, D. (2002). Rethinking University Teaching (pp. 1-268). London: RoutledgeFalmer. Retrieved 22 September 2013 from http://lsm.dei.uc.pt/ribie/docfiles/txt200342319328001_DIANNE\%20 LAURILLARD.PDF

Lehrer, R. (1993). Authors of knowledge: Patterns of hypermedia design. In S.P. LaJoie and S. J. Derry (Eds.), Computers as cognitive tools (pp. 197-227). Hillsdale, NJ: Erlbaum.

Luckin, R. (2010) Re-designing Learning Contexts: Technology-Rich, Learner-Centred Ecologies. London, Routledge.

Marlowe, B. A., \& Page, M. L. (2005). Creating and Sustaining the Constructivist Classroom. Thousand Oaks, CA. Corwin Press.

Morrison, G. R., \& Lowther, D. L. (2002). Integrating computer technology into the classroom. 2nd edition. Upper Saddle River, NJ: Merrill/Prentice Hall.

Mullis, V. S., Martin, M. O., Kennedy, A. M., \& Foy, P. (2007). IEA's Progress in International Reading Literacy Study in Primary School in 40 Countries. Chestnut Hill, MA: TIMSS \& PIRLS International Study Center, Boston College. Retrieved 22 September 2013 from http://timss. bc.edu/PDF/PIRLS2006_international_report.pdf

Murphy, E., \& Rodriguez-Manzanares, M. A. (2008). Using activity theory and its principle of contradictions to guide research in educational technology. Australasian Journal of Educational Technology, 24 (4), 442-457. Retrieved May 18, 2009 from http://www.ascilite.org.au/ajet/ ajet24/murphy.html

Norris, S. P., Phillips, L. M. (2003). How literacy in its fundamental sense is central to scientific literacy. Science Education, 87, 224-240.

OECD (2013). PISA 2012 Assessment and Analytical Framework: Mathematics, Reading, Science, Problem Solving and Financial Literacy, OECD Publishing. Retrieved 22 September 2013 from doi: http://dx.doi.org/10.1787/9789264190511-en

Osborne, J. (2010). Arguing to Learn in Science: The Role of Collaborative, Critical Discourse. Science, 328, 463-466.

Papert, S. (1991). Situating Constructionism. In I. Harel and S. Papert (Eds.) (1991). Constructionism: Research Reports and Essays 1985-1990 by the Epistemology and Learning Research Group (pp. 1-12). New Jersey: Ablex.

Pearson, P. D., Moje, E. B., \& Greenleaf, C. (2010). Literacy and Science: Each in the service of the other. Science, 328, 459-463.

Perkins, D. N. (1986). Knowledge as Design. Hillsdale, NJ: Erlbaum.

Pinnock, R. (2013). SA education system is failing pupils, economy. Cape Times, 5 September, 2013. Retrieved 22 September 2013 from http://www.iol.co.za/capetimes/sa-education-system-isfailing-pupils-economy-1.1573771

Prensky, M. (2001b). Digital Natives, Digital Immigrants (From On the Horizon, NCB University Press, Vol. 9 No. 5, October 2001). Retrieved February 25, 2008 from http://www.marcprensky.com/ writing/Prensky\%20-\%20Digital\%20Natives,\%20Digital\%20Immigrants\%20-\%20Part1.pdf

Roth, W., \& Lee, Y. (2007). "Vygotsky's Neglected Legacy": Cultural-Historical Activity Theory. Review of Educational Research., 77 (2), 186-232.

Siemens, G., \& Tittenberger, P. (2009). Handbook of emerging technologies for learning. Retrieved 22 September 2013 from http://elearnspace.org/Articles/HETL.pdf 
Sinclair, M. (2004). Complexity theory and the mathematics lab-classroom. Complicity: An international journal of complexity and education, 1 (1), 57-71.

Spaull, N. (2012). Education in SA: A tale of two systems. Politics Web, 31 August 2012. Retrieved 22 September 2013 from http://www.politicsweb.co.za/politicsweb/view/politicsweb/en/page7161 9?oid $=323272 \&$ sn $=$ Detail\&pid $=71616$

Steketee, C. (2002). Students' Perceptions of Cognitive Tools and Distributed Learning Environments. HERDSA, pp. 626-633. Retrieved 20 September 2013 from www.herdsa.org.au/wp-content/ uploads/conference/2002/papers/Steketee.pdf

Taylor, N, Fleisch, B, Shindler, J. (2008). Changes in Education since 1994. Background paper for the Fifteen Year Review of government business, commissioned by the Policy Unit, Office of the Presidency.

Thier, M. (2010). Science and Literacy: Tools for Life. Science Scope, 33 (6), 32-35.

Villanueva, M. G., \& Hand, B. (2011). Science for All: Engaging Students with Special Needs in and About Science. Learning Disabilities Research \& Practice, 26 (4), 233-240.

Villanueva, M. G., \& Webb, P. (2008). Scientific investigations: The effect of the 'Science Notebooks' approach in Grade 6 classrooms in Port Elizabeth, South Africa. African Journal of Research in Mathematics, Science and Technology Education, 12 (2), 5-18.

Webb, P. (2009). Towards an integrated learning strategies approach to promoting scientific literacy in the South African context. International Journal of Environmental and Science Education, 4 (3), 313-334.

Webb, P. (2010). Science education and literacy: Imperatives for the developed and developing world. Science, 328 (5977), 448 - 450.

Webb, P., \& Mayaba, N. (2010). The effect of an integrated strategies approach to promoting scientific literacy on grade 6 and 7 learner's general literacy skills. African Journal of Research in Mathematics, Science and Technology Education, 14 (3), 35-50.

Webb, P., \& Treagust, D. F. (2006). "Using Exploratory Talk to Enhance Problem-Solving and Reasoning Skills in Grade-7 Science Classrooms." Research in Science Education, 36 (4), 381-401.

Wegerif, R., \& Mercer, N. (1997a). A dialogical framework for researching peer talk. In R. Wegerif \& P. Scrimshaw (Eds.), Computers and Talk in the Primary Classroom, (pp. 49-65). Clevedon: Multilingual Matters.

Wenger, E. (1998). Communities of Practice: Learning, Meaning and Identity. Cambridge: Cambridge University Press.

Wilkinson, \& Rademeyer (2013). Is SA's education system the worst in Africa? Not according to the data. Africa Check: Sorting Fact from Fiction. 04 September, 2013. Retrieved 22 September 2013 from http://www.africacheck.org/reports/is-sas-education-system-the-worst-in-africa-notaccording-to-the-data/

Wilson, L. (2005). Beyond Bloom - A New Version of the Cognitive Taxonomy. Retrieved 22 September 2013 from http://www.uwsp.edu/education/lwilson/curric/newtaxonomy.htm

Yore, L. D., Pimm, D., \& Tuan, H. L. (Eds.). (2007). Language-An end and a means to mathematical literacy and scientific literacy [Special issue]. International Journal of Science and Mathematics Education, 5 (4), 557-769.

Advised by Vincentas Lamanauskas, University of Siauliai, Lithuania

Received: September 15, 2013

Accepted: December 08, 2013

André du Plessis

Ph.D., Senior Lecturer, Faculty of Education, Nelson Mandela Metropolitan University, PO Box 77000, Port Elizabeth, 6031, South Africa.

E-mail: andre.duplessis@nmmu.ac.za

Website: http://www.nmmu.ac.za/helpingteachers/individualprojectduplessis/index.htm 